\title{
WEED CONTROL BY CULTIVATION AND SPRAYING
}

\author{
By - Mr.R.G. Allen, Southbridge,
}

A property of 340 acres was taken over $12 \frac{1}{2}$ years ago. This property had been neglected badly in every respect. The weeds which gave the most trouble were :- Wild turnip, Californian thistle, Wild. tares, Fat-hen, Twitch, and Wild Oats.

\section{WIID TURNIP}

(1) Wild turnip is most troublesome in spring sown crops, especially in garden peas. The method used for control was Winter deep-rloughing, then cultivation in spring, with grubbing; gradually grubbing shallower each time, so as not to bring up fresh wild turnip seeds.

When the spring crop is sown, harrowing is the most important, this being done as often as four times, if weather conditions are suitable.

\section{CALIFORNIAN THISTLE}

(2) The Californian Thistle is certainly a difficult weed to handle in crops at harvest time, but unlike wild turnips and tares, it can be killed in one year by cultivation at all possible times. When a crop has been harvested, I burn off the stubble at once, and plough. If after three or four years cropping, the thistle is increasing, I give the paddock a summer fallow, first ploughing the paddock and then grubbing with eleven inch points. Grubbing is done whenever the thistle appears above the ground. I endeavour to fallow one paddock each summer, I find this method al so kills many strikes of other small seeds, such as tares and turnips.

Through adopting this method of control I have several paddocks free from thistle.

I have 24 acres in lucerne, which proves a sure kill for thistle. With cutting the lucerne 4 or 5 times in the summer, the thistle has no hope of survival.

Cocksfoot is another good control. I have 30 acres in cocksfoot; one paddock is kept for seed each year; the other paddock is now grazed. The paddock which is seeded has the thistle completely s nothered. When grazing cocksfoot too hard, odd thistles will appear.

\section{WIID TARES}

3. The only method of reducing these is to try and get them to germinate before sowing.

\section{FAT-HEN}

4. It is most troublesome in a paddock sown in peas.

\section{TWITCH}

5. Twitch must be cultivated when ground is dry (a summer jo's, and. followed with autumn sheep feed.

\section{WILD OATS}

6. If a paddock is very bad with wild oats, put sheep feed in three years running. Plough each year before sowing and eat of greenfeed before the wild oats come to ear. Sow Italian ryegrass or rape. The first ploughing should be the deepest, then gradually a little less each ploughing.

\section{WILD TURNIP}

7. I consider the expense of buying a machine and the cost of spray to deal with wild turnip alone, is the best investment anj farmer could make. The amount of spray used on padcincks of wheat, per acre, was 
one quart of Weedar in 8 gallons of water, put on at $251 \mathrm{bs}$ pressure to kill wild turnip. The yield was 15 bushels per acre above the non-sprayed portion. The spray also had good effect on the tares. The cost was \&1 per acre.

\section{SPRAY ON CALIFORNIAN THISTLEE}

You can spray with good effect on cereal crops, to control the thistle. It may not kill the thistle but will put them down to the ground for the harvest.

\section{SPRAYING GARDEN PEAS}

Through being able to spray wild turnips among peas, I can sow peas in paddocks, I would not have been able to use before and be sure of getting a crop.

The spray used on peas was:- Sinox, one gallon to 25 gallons of water, at $251 \mathrm{bs}$ pressure, per acre. (Cost £1. 2. 6)

Sinox will not kill thistles.

Farmers must not expect spraying to give good yields unless they do their part in respect to tillage of the soil. 